\title{
Mutual Fund Performance in Slovenia: An Analysis of Mutual Funds with Investment Policies in Europe and the Energy Sector
}

Tanja Markovič Hribernik, Uroš Vek *

Abstract:

This paper examines the risk and return performance of mutual funds in Slovenia from 2005 until August 2009. The research is limited to the regional investment policies in Europe and the energy sector. Using monthly returns, we analyzed different risk-adjusted measures such as: the Treynor ratio, the Sortino ratio and the Information ratio. We also studied selections and timing ability using the Treynor-Mazuy model. The risk and return performance of mutual funds in the Slovenian market does not deviate from those in developed markets. We also found out that the selection ability of fund managers is better than market timing and that the findings of this paper are in accordance with other international studies.

Keywords: mutual funds, investment policy, risk adjusted measures, Slovenia, Europe

JEL: G11

DOI: 10.2478/v10033-011-0006-y

\section{Introduction}

The development of the Slovenian capital market has its roots in early 1990. Citizens came into contact with capital investments through privatization. They received certificates that allowed them to buy shares of different companies. The next step in the development of the capital market was the introduction of closed investment funds and mutual funds. From that point on, the mutual fund industry made rapid progress and is still, despite the financial crisis, a success story. The number of investors increased to 20 percent of the entire population of Slovenia by the end of September 2009.

Funds are often the subject of research and analysis, all sharing the aim of finding the best performing fund relative to the benchmark. Investors focus a great deal of attention on the historical returns of a fund when making investment decisions. They disregard the fact that historical returns do not assure future returns.

Investment and portfolio theory has introduced plenty of measures to compare the risk and returns of a fund. The theory appeared with the publication of an article by William Sharpe (1966) in which he first presented a measure of excess returns per unit of risk. The unit of risk was standard deviation.

This paper will analyze mutual fund performance in Slovenia with the regional investment policy of Europe in the energy sector from 2005 until August 2009. The aim of the study is to find the best performing funds in their investment policies and to examine Slovenian fund managers' competitiveness compared to fund managers of other countries. We will introduce different riskadjusted return measures, such as: $\mathrm{M}^{2}$, the Treynor ratio, the Sortino ratio, the Information ratio and examine

\footnotetext{
* Tanja Markovič Hribernik

University of Maribor,

Faculty of Business and Economics

E-mail: tanja.markovic@uni-mb.si

\section{Uroš Vek}

KBM Infond d.o.o., Asset Managment Company -

Group Nova KBM

E-mail: urosvek88@yahoo.com
} 
selection ability with Jensens Alpha, and timing ability with the Treynor-Mazuy model.

\section{Methodology}

\subsection{Theoretical Background of Modern Portfolio Theory}

One of the first researchers of modern finance was Markowitz (1952) with his study of the implication of diversification on risk and the return characteristics of a portfolio. He showed increasing diversification lowered the portfolio's standard deviation and variance. The set of portfolios that have the highest expected returns for a given level of risk form an Efficient Frontier.

Studies of mutual fund performance started getting more attention from 1960 on with the introduction of the Capital Asset Pricing Model (CAPM) by William Sharpe (1964) (who for his work in the field of finance received a Nobel Prize in 1990) and John Lintner (1965). The CAPM (the model is presented in detail in the next section) is the pillar and the groundwork of Modern Portfolio Theory (MPT) which explains the relation between expected returns and risk. The aim is to maximize the expected returns of a portfolio for a given amount of risk. It became the mainstream occupation of financial literature in the years following its introduction.

In the early period, authors like Sharpe (1964), Jensen (1968) and Treynor (1965) marked the scientific contribution to the field of mutual fund performance with the implication of the CAPM and received great attention in the financial community. They also introduced several risk and return measures for the evaluation of mutual fund performance that are widely used in finance.

The theoretical dominance of the CAPM was challenged in the following periods by concentrating on anomalies of the CAPM. The assumptions on which the model is based represent an idealized, rather than real world. Roll (1977) pointed out that the CAPM could never really be tested because the market portfolio was unmeasurable. Fama and French (2004) claimed that the CAPM has never been an empirical success. If we include size and market to book value in the model, beta becomes insignificant.

Regardless of rising criticism, the CAPM remains a very useful financial toolkit for several reasons as pointed out by Head (2008). First, it considers only systematic risk, which reflects the reality in which most investors have diversified portfolios. It states a theoretical relationship between required rate of returns and systematic risk and it is a much better method of calculating the cost of equity than the dividend growth model. Finally, it is superior to the WACC in providing discount rates for use in investment appraisal.

As noted by Sharpe (1966): "The theory of portfolio analysis is essentially normative as it describes efficient techniques for selecting portfolios on the basis of predicitions about the performance of individual securities." The final "analysis" or choice for specific mutual fund is made by the investor and is the combination of his preferred risk and returns. The purpose of mutual fund studies is to reveal those that have the greatest expected returns for a given level of risk.

In this paper we focused our study on the mutual fund market of Slovenia based on the findings, risk and return measures of the early period of Modern Portfolio Theory.

\subsection{Risk and Return Measures}

Modern Portfolio Theory uses a Capital Asset Pricing Model - CAPM $^{1}$ to estimate the expected returns of mutual funds, which is a linear function of systematic risk (beta) and selection ability (a). The fund's return is equal to the returns on a risk-free asset, market premium and the selection ability of the fund manager.

$$
R_{i, t}=\alpha_{i}+R_{f, t}+\beta_{i}\left(R_{m, t}-R_{f, t}\right)+\varepsilon_{i, t}
$$

$R_{i, t}$ is the return of fund $\mathrm{i}, R_{f, t}$ risk-free return, $R_{m, t}$ market return. $\beta_{i}$ is a measure of systematic risk and shows the market exposure of the fund and $\varepsilon_{i, t}$ is stochastic and a fund-specific return. A risk-free asset is by definition not exposed to the market, so the systematic risk is 0 . If the fund's actual return is higher than the expected return, calculated with the CAPM, the fund manager shows selection ability. In equation 1 , the constant measures the manager's selection ability. $a>0$ states that the manager is superior to the market in stock picking and vice versa if $a<0$.

In 1966, Treynor-Mazuy presented a modification of CAPM to assess a manager's ability to predict market fluctuations.

\footnotetext{
${ }^{1}$ The model was first introduced by Jack Treynor (1961-1962), William F. Sharpe (1964), John Lintner (1965) and John Mossin (1966) independently, yet all were based on the earlier work of Harry Markowitz on diversification and modern portfolio theory
} 


$$
\begin{aligned}
& R_{i, t}=\alpha_{i}+R_{f, t}+\beta_{i}\left(R_{m, t}-R_{f, t}\right)+\gamma_{i}\left(R_{m, t}-\right. \\
& \left.R_{f, t}\right)^{2}+\varepsilon_{i, t}
\end{aligned}
$$

$a$ is a measure of selection ability and $\gamma$ of market timing. If the Treynor-Mazuy coefficient is positive, the fund manager is able to shift from high-beta stock to lowbeta stock when the market falls. If the coefficient is negative, the manager is not able to properly asses the market conditions and shift from high-beta stock to lowbeta stock when the market falls.

In this paper, we decided to value the funds' performance with absolute risk-adjusted return measures $\left(\mathrm{M}^{2}\right.$, Treynor ratio, Treynor-Mazuy), relative (Information ratio) and downside risk-adjusted returns.

Modigliani (1997) first introduced $M^{2}$ to compare returns that have been adjusted to risk. The coefficient is a modified Sharp ratio, which shows the return per unit of risk and puts the benchmark and fund on the same risk basis.

$\mathrm{M}^{2}=\left[\left(\frac{\overline{R P_{i}}-\overline{R F_{i}}}{\sigma_{i} \times \sqrt{P}}\right) \times\left(\sigma_{j} \times \sqrt{P}\right)\right]+\overline{R F_{i}}$

where: $\overline{R P}_{i}$ is the average return of the fund $i, \overline{R F}_{i}$ is the average return of a risk-free asset $i, \sigma_{i}$ is the standard deviation of the fund $i, \sigma_{j}$ is the standard deviation of the benchmark $j$, and $P$ is the number of observations in a year.

The total risk is $\sigma^{2}=\beta^{2} \sigma_{m}^{2}+\sigma_{e}^{2}$, which can be divided into systematic risk and unsystematic risk. With diversification, unsystematic risk can be reduced, but one can not avoid systematic risk when investing in the stock market.

The Treynor ratio is calculated by dividing excess returns with market or systematic risk ( $\beta$ ). The fund lacks proper diversification if $\mathrm{M}^{2}$ is low while the Treynor ratio is high.

$$
T_{p}=\left(\frac{\overline{R P_{i}}-\overline{R F_{i}}}{\beta_{i}}\right)
$$

where: $\overline{R P}_{i}$ is the average return of fund $i, \overline{R F}_{i}$ is the average return of risk free asset $i$ and $\beta_{i}$ is the measure of market or systematic risk $i$.
William F. Sharpe is the author of the information ratio, whose average value added over the benchmark divides by its standard deviation:

$$
I R=\frac{\left(\frac{\sum R P_{i}-R M_{i}}{N}\right) \times \sqrt{P}}{\sigma\left(R P_{i}-R M_{i}\right) \times \sqrt{P}}
$$

where: $R P_{i}$ is the return of fund $i, R M_{i}$ is the return on benchmark $i, \sigma\left(R P_{i}-R M_{i}\right)$ is the standard deviation of value added $i, N$ is the number of observations, and $P$ is the number of observations in a year.

The Sortino ratio is a measure of downside risk, where positive returns are not observed. In the denominator only returns that are smaller than the target return ( $\mathrm{T}$ ) are considered. The ratio measures excess return to downside risk taken.

$$
S=\frac{\left(\overline{R P_{i}}-T\right) \times P}{\left(\sqrt{\frac{\sum\left(R P_{i}-T\right)^{2} ; R P_{i}<T}{N}}\right) \times \sqrt{P}}
$$

where: $R P_{i}$ is the return of a fund $i, \overline{R P}$ is the average return on the fund $i, T$ is the target rate of return, $N$ is the number of observations, and $P$ is the number of observations in a year.

\section{Data}

The research includes comparable mutual funds that were present in the Slovenian market at the end of 2008. The funds were selected in accordance with geographical investment policies in Europe and in the energy sector.

Funds within the investment policy of the energy sector had to satisfy certain criteria: the fund had to have at least $75 \%$ of its assets in shares of companies which produce and distribute oil, gas and electricity; mining coal and uranium; producing equipment for energy companies; or producing and investing in R\&D of renewable energy sources.

Funds within the geographical investment policy of Europe had to have at least $75 \%$ of their assets in shares of companies that have headquarters or the major part of business operations within the European Union. More 
than $50 \%$ of their assets had to be held in shares of companies located outside Slovenia.

Mutual funds were observed 33 times, all ending at the same point in time. In the research we used log monthly returns $R_{i, t}=\ln \left(S_{i, t} / S_{i, t-1}\right)$, where $S_{i, t}$ is the monthly return of a fund $i$ in month $t$. When analyzing funds within the investment policy of Europe, we used the 10-year German Bund as a risk-free rate of return and the benchmark of MSCl Europe. The risk-free asset, when analyzing funds within investment policy in the energy sector, was compounded by 10-year German, Japanese and USA bonds, and the benchmark was MSCI ENERGY in euros.

\section{Results of Analysis}

In accordance with EFAMA (2008) Slovenia had the highest growth of mutual fund assets in 2007 with $45.9 \%$. In that same year, the market of mutual funds reached a size of $€ 2.97$ billion. The reason was the Slovenian stock market and the high net inflows of money to mutual funds. The performance of the Slovenian stock market index was more than $70 \%$ and was one of the best performing indices in the world in 2007. A particular characteristic of the Slovenian investor was his high risk profile. The structure of mutual funds assets was dominated by equity funds. At the peak of the market in 2007 , equity funds represented $66 \%$ of all mutual fund assets. The share of equity funds to total assets in the European Union was $41 \%$. Net withdrawals and drops in equity prices, as a result of the financial crisis, started to shift the structure of mutual fund assets in Slovenia toward EU standards.

The mutual fund market in Slovenia shrank to 1.75 billion euros in September 2009. However, this is still 91\% higher than at the beginning of 2005. In addition to asset growth, the number of investors in mutual funds jumped $200 \%$ to 393,000 .

\subsection{Analysis of Mutual Fund Performance with Investment Policies in Europe}

First, we started estimating the CAPM (equation 1) with the standard method of linear regression: ordinary least square. In the Slovenian mutual fund market there were seven funds present with investment policies in Europe at the end of 2008. Table 2 shows the results of estimating CAPM and the Treynor-Mazuy model (equation 2) for the period from 2005 to August 2009.
NLB-Evropski delniški started in September 2005 and therefore was observed at only 47 points, which resulted in a worse monthly average return because in the year 2005 European equities surged. The financial crisis is reflected in the numbers we obtained. The average monthly log return of some funds and the benchmark was negative. The best performing fund, PIA-Select Europe Stock, had an average monthly log return of $0.05 \%$, followed by VB-Europa Invest with $0.04 \%$.

When comparing the risks and returns of the two best performing funds we can see that PIA- Select Europe Stock achieved a higher return with lower risk than VBEuropa Invest. All funds except PF-Top European Players had a higher standard deviation than the benchmark, but only four outperformed the benchmark. Higher risk taking was profitable for only half of the funds, which had higher average monthly log returns than the benchmark.

The benchmark MSCl Europe explains the mutual funds returns with $\mathrm{R}^{2}$-statistics between 0.8-0.997. The beta of funds is in the range of 1-1.35. VB-Europe Invest can be pointed out with a beta of 1.35. Low $\mathrm{R}^{2}$, high beta and high standard deviation can be explained by a riskier investment policy. The fund had invested more in one sector or region than the benchmark.

When analyzing the market timing ability of funds with the Treynor-Mazuy model (equation 2) only two out of seven funds had a positive $\gamma$ coefficient and none of them were significant at the $5 \%$ level. The majority of funds had negative $\gamma$ coefficients, which means that managers increased their holdings of high beta stocks when the market performed poorly and vice versa. We can conclude that the fund managers lacked market timing ability when making investment decisions. This is in accordance with the findings of Chucky and Glen (1990) and Jagrič (2007).

Table 3 shows the risk adjusted statistics of the $M^{2}$, Treynor ratio, Sortino ratio, Information ratio and acoefficient. Funds are sorted in accordance with $\mathrm{M}^{2}$, where a higher positive value represents a better relationship between risk and return. The average monthly log return for the majority of funds was negative - as well as $\mathrm{M}^{2}$. In this case, the fund with a lower negative value for $\mathrm{M}^{2}$ represents a better relationship between risk and return. The funds VB-Europa Invest and PIA-Select Europe Stock had a positive $M^{2}$ value, while the others had negative values. Other ratios reflect the performance of funds in a similar classification as $\mathrm{M}^{2}$.

Six out of the eight funds had a positive coefficient a but with a low nominal value (third decimal). The only 
statistically significant, at a 5\% level, was SGAM FundEquities Europe. These results are comparable to Ippolito (1989), who, in researching 143 funds, found that 127 funds had a 0,12 funds were positive and 4 funds were negative.

The analysis of mutual funds with investment policies in Europe includes two Slovenian managed funds: Infond Europa and NLB-Evropski delniški. On the basis of this analysis, we can say they do not lag behind in return and risk when compared with the relatively strong European competition. The funds are competitive even if they were present on the market for around five to six years and were able to offer investors returns comparable to strong European competitors.

\subsection{Analysis of Mutual Fund Performance in Investment Policy in the Energy Sector}

Table 4 shows the results for nine funds with an investment policy in the energy sector. The average monthly log return for the benchmark in the period from January 2005 until August 2009 was $0.3 \%$. The majority of funds had negative average monthly log returns. The Slovenian mutual funds had higher negative average returns. This is due to the fact that they were introduced to the market after January 2005. Infond Energy and MPEnergy started in October 2005, while Ilirika-Modra energija began in November 2006. Slovenian fund managers were not able to compete during the time when markets were surging. This fact has to be remembered when interpreting the results.

The best performing fund was PIA-Energy Stock, with an average monthly log return of $0.57 \%$. In addition to the PIA-Energy Stock, two other funds outperformed the benchmark with an average return of $0.3 \%$. Seven out of nine funds had a standard deviation higher than the benchmark. EEF-Energy\&Materials was able to outperform the benchmark while having a lower standard deviation and therefore being less risky.

The benchmark MSCl World Energy Index does not explain fund returns as well as $\mathrm{MSCl}$ Europe. The $\mathrm{R}^{2}$ statistics range from 0.649 to 0.914 , while the beta stretched from 0.867 to 1.044 -- all significant at a level of $5 \%$.

When analyzing the Treynor-Mazuy model, we came to the same conclusion as in subchapter 4.1: fund managers lack the ability to correctly predict market fluctuations. The coefficient $\gamma$ was negative for all funds.
Table 5 shows risk adjusted statistics for funds with investment policies in the energy sector. Funds are sorted in accordance with $\mathrm{M}^{2}$ performance. PIA-Energy Stock has the best relationship between risk and return, followed by Raiffeisen Energie Aktien. The two funds with the highest $\mathrm{M}^{2}$ value also have higher Treynor ratios. They were rewarded for taking higher risks, which is reflected in other ratios as well. The beta of both funds is higher than 1 and the standard deviation is higher than the benchmark.

\section{Conclusions}

We analyzed mutual fund performance in Slovenia to discover the quality of fund managers of investment policy within the areas of Europe and the energy sector. Up until the beginning of the financial crisis, Slovenia was marked by exceptionally high growth rates in the mutual fund industry. The reasons for this were in the performance of the Slovenian stock market index, which was one of the best performing markets in 2007, with a growth of more than $70 \%$. Additionally, the number of investors and mutual funds increased. This was all supported by a good macroeconomic picture of low budget deficits and public debt, which deteriorated during the financial crisis. Slovenia in 2009 registered a budget deficit of around 5.5\% and a public debt of around 36\% (SURS 2010).

During the period of economic success, investors did not pay much attention to the risk and returns analysis. With the financial crisis, investors became more aware of the fact that risk goes hand in hand with returns.

The success story for the mutual fund industry ended with the financial crisis, which caused net outflows of assets of $€ 304$ million in 2008. This represented $10 \%$ of all assets in 2007. According to EFAMA, in Europe the net outflow of assets in 2008 accounted for only $4.4 \%$ of all assets. The Slovenian mutual fund industry is still far away from EU standards. The structure of Slovenian household financial assets (Banka Slovenije 2009) consists of 6.3\% of assets in investment funds (mutual funds and investment companies), while in Europe it is $9.1 \%$. The share of deposits and cash in Slovenia is $49.9 \%$, while in Europe it is $42 \%$. When we compare investment fund assets to national GDP, we see that in Slovenia, investment fund assets represent $5.1 \%$ of GDP, while in Europe it is $45.9 \%$. These figures show the potential of the domestic mutual fund market despite its development in the past. 
In the analysis of the performance of mutual funds in Slovenia from January 2005 until August 2009, we used the monthly log returns of funds. The research included mutual funds that were present on the market at the end of 2008. The focus was on funds with investment policies in Europe and the energy sector. With the CAPM and Treynor-Mazuy model, we examined both selection and market timing ability. Selection ability shows if a fund manager is superior in stock picking in comparison to the market. Fund managers who are capable of shifting from high beta stocks to low beta stocks when the market falls exhibit market timing ability.

When analyzing selection ability, only one fund was superior to the market in stock picking, while the majority of fund managers had a positive coefficient, but none significant at the $5 \%$ level. The results of the market timing analysis states that fund managers were not able to properly predict market fluctuations. Only two out of seventeen funds had a positive market timing coefficient, while all of the others were negative. However, none of the coefficients of the analyzed funds were statistically significant. We can state that fund managers are better at stock picking than in predicting market fluctuations. In this paper, we reject the selection and market timing ability of fund managers. This conclusion is in accordance with other empirical studies. ${ }^{2}$

The results show that the Slovenian fund managers of investment policies in Europe have comparable risk and return characteristics to foreign mutual fund managers in developed European markets that have several years of experience. The comparison of investment managers of investment policies in the energy sector is not appropriate because the majority of Slovenian mutual funds yielded fewer opportunities for observation than their European counterparts. This is due to the fact that they were introduced to the market later than 2005, while the analysis was for the period from 2005 until August 2009. ㅁ.

\section{References}

ATVP-Securities Market Agency. 2009. Podatkovno ogledalo. (database online) http://www.a-tvp.si/Default.aspx?id=55 (accessed 25.10.2008).

Bank of Slovenia. 2009. Poročilo o finančni stabilnosti. (database online) http://www.bsi.si/publikacije-in-raziskave.asp?Mapald=285 (accessed 18.06.2009).
Chumby, R. in Glen, J. 1990. Evaluating the performance of international mutual funds. Journal of Finance, Vol. 45, 497-521.

EFAMA-European Fund and Asset Management Association. 2008. Efama Fact Book - Trends in European Investmen Funds $6^{\text {th }}$ Edition. EFAMA 2008.

EFAMA-European Fund and Asset Management Association. 2009. Efama Fact Book - Trends in European Investmen Funds $7^{\text {th }}$ Edition. EFAMA 2009.

Fama, F. Eugene and French, R. Kenneth. 2004. The Capital Asset Pricing Model: Theory and Evidence. Journal of Economic Perspectives, Vol. 18-3, 25-46.

Feibel, Bruce J. 2003. Investment performance measurement. New Jersey: John Wiley \& Sons, Inc.

Head, Tony. 2008. CAPM: Theory, advantages and disadvantages. ACCA- Student Accountant Magazine, 2008, 51-53.

Ippolito, R. 1989. Efficiency wiht Costly Information: A study of Mutual Fund Performance, Quarterly Journal of Economics, Vol. 104, 123.

Jagrič, T., Podobnik, B., Balen, V., Kalanović, M. in Jagrič, V. 2007. Stock Market Performance Analysis for Three European Emerging Stock Markets. The Business Review, Summer 2007, 8.

Jensen, C. Michael. 1968. The Performance of Mutual Funds in the Period 1945-1964. The Journal of Finance, Vol. 23-2, 389-416

KD Finančna točka. (2009). Vzajemni skladi - Arhiv. (database online). http://www.financna-tocka.si_(10.10.2009).

Lintner, John. 1965. The Valuation of Risk Assets and the Selection or Risky Investments in Stock Portfolios and Capital Budgetes. Review of Economics and Statistics, Vol. 47-1, 13-37.

Markowitz, M. Harry. 1952. Portfolio Selection. The Journal of Finance, Vol. 7, 77-91.

Sharpe, F. William. 1964. Capital Asset Prices: A Theory of Market Equilibrium under Conditions of Risk. Journal of Finance, Vol. 19-3, 425442.

Sharpe, F. William. 1966. Mutual Fund Performance. Journal of Business, Vol. 39, 119-138.

Roll, Richard. 1977. A critique of the asset pricing theory's tests Part I: On past and potential testability of the theory. Journal of Financial Economics, Vol. 4-2, 129-176.

Treynor, J. 1965. How to rate management investment funds. Harvard Business Review, Vol. 43, January-February, 63-75.

Treynor, J. in Mazuy, K. 1966. Can Mutal Funds Outguess the Market? Harvard Business Review, Vol. 43 July-August,131-136.

SURS - Statistical Office of the Republic of Slovenia. (2010). Primanjkljaj in dolg države. (database online). http://www.stat.si/indikatorji.asp?ID=28 (10.05.2010).

\footnotetext{
${ }^{2}$ The findings of Jagrič (2007), Chucky and Glen (1990) and Ippolito (1989) show similar results.
} 


\section{Tables}

\begin{tabular}{|c|c|c|c|c|c|c|c|}
\hline Mutual Funds & $\mathbf{N}$ & Introduction of funds & 2005 & 2006 & 2007 & 2008 & 2009* \\
\hline EUROPE & & & $\%$ & $\%$ & $\%$ & $\%$ & $\%$ \\
\hline Infond Europa & 56 & oct.04 & 20.95 & 18.09 & 10.89 & -51.73 & 19.97 \\
\hline NLB-Evropski delniški & 47 & sep.05 & 6.00 & 18.10 & 2.49 & -42.80 & 22.22 \\
\hline PF-Top European Players & 56 & dec.00 & 23.74 & 17.49 & -8.38 & -46.06 & 21.35 \\
\hline VB-Europa Invest & 56 & okt.89 & 28.18 & 24.48 & -6.25 & -50.22 & 37.48 \\
\hline PIA-Select Europe Stock & 56 & dec.56 & 26.69 & 13.60 & 1.51 & -43.54 & 24.37 \\
\hline SGAM-Equities Europe & 56 & may.88 & 25.18 & 15.16 & -1.16 & -48.96 & 22.73 \\
\hline Raiffeisen Europa Aktien & 56 & jun.96 & 25.31 & 18.22 & -2.87 & -50.27 & 32.89 \\
\hline EEF-Equity Europe & 56 & jun.01 & 22.81 & 17.81 & 0.29 & -45.04 & 20.52 \\
\hline MSCI EUROPE INDEX & & dec.98 & 22.77 & 16.49 & 0.07 & -45.52 & 18.26 \\
\hline
\end{tabular}

\begin{tabular}{|c|c|c|c|c|c|c|c|}
\hline ENERGY & & & $\%$ & $\%$ & $\%$ & $\%$ & $\%$ \\
\hline Infond Energy & 46 & oct.05 & -0.12 & 16.46 & 25.42 & -47.80 & 24.52 \\
\hline KD-Surovine in energija & 39 & may.06 & - & 10.55 & 21.91 & -46.98 & 22.48 \\
\hline EEF-Energy\&Materials & 56 & jul.00 & 42.05 & 6.26 & 15.71 & -41.81 & 17.12 \\
\hline Ilirika-Modra energija & 33 & nov.06 & - & 1.44 & 13.07 & -45.40 & 18.37 \\
\hline MP-Energy & 46 & oct.05 & 18.47 & 9.72 & 7.93 & -50.09 & 31.31 \\
\hline NLB-Naravni viri & 43 & jan.06 & - & 12.95 & 21.87 & -43.38 & 25.23 \\
\hline PIA-Energy Stock & 56 & jun.01 & 53.04 & 13.41 & 24.31 & -48.71 & 24.48 \\
\hline Raiffeisen Energie Aktien & 56 & feb.02 & 50.03 & 13.29 & 14.03 & -48.58 & 26.36 \\
\hline SGAM-Global Energy & 56 & oct.98 & 12.73 & -6.77 & 20.14 & -40.19 & 10.35 \\
\hline MSCI WORLD ENERGY INDEX & & dec.98 & 44.57 & 3.90 & 15.30 & -36.61 & 7.96 \\
\hline
\end{tabular}

${ }^{*}$ till 31.8.2009

Source: Finančna točka 2009

Table 1: General figures 


\begin{tabular}{|c|c|c|c|c|c|c|}
\hline Mutual fund & $\boldsymbol{\mu}$ & $\boldsymbol{\sigma}_{\mathrm{d}}$ & $\boldsymbol{\beta}$ & $\mathbf{R}^{2}$ & $\beta^{*}$ & $\mathbf{Y}$ \\
\hline Infond Europa & -0.0015 & 0.06075 & $\begin{array}{c}1.134 \\
(18.516)\end{array}$ & 0.864 & $\begin{array}{c}1.012 \\
(15.888)\end{array}$ & $\begin{array}{l}-2.633 \\
(-3.773)\end{array}$ \\
\hline NLB-Evropski delniški & -0.0023 & 0.05006 & $1.01(27.61)$ & 0.944 & $\begin{array}{c}1.008 \\
(23.492)\end{array}$ & $\begin{array}{c}-0.03 \\
(-0.065)\end{array}$ \\
\hline PF-Top European Players & -0.0025 & 0.04940 & $\begin{array}{c}0.971 \\
(34.884)\end{array}$ & 0.958 & $\begin{array}{c}0.995 \\
(31.138)\end{array}$ & $\begin{array}{l}0.519 \\
(1.48)\end{array}$ \\
\hline VB-Europa Invest & 0.0004 & 0.07540 & $\begin{array}{c}1.356 \\
(14.805)\end{array}$ & 0.802 & $\begin{array}{c}1.316 \\
(12.324)\end{array}$ & $\begin{array}{c}-0.876 \\
(-0.749)\end{array}$ \\
\hline PIA -Select Europe Stock & 0.0005 & 0.05161 & $\begin{array}{c}0.998 \\
(26.308)\end{array}$ & 0.927 & $0.996(22.4)$ & $\begin{array}{c}-0.057 \\
(-0.117)\end{array}$ \\
\hline SGAM-Equities Europe & -0.002 & 0.05775 & $\begin{array}{c}1.093 \\
(20.706)\end{array}$ & 0.888 & $\begin{array}{c}1.013 \\
(17.498)\end{array}$ & $\begin{array}{c}-1.745 \\
(-2.751)\end{array}$ \\
\hline Raiffeisen Europa Aktien & -0.0009 & 0.06178 & $1.2(27.852)$ & 0.935 & $\begin{array}{c}1.171 \\
(23.486)\end{array}$ & $\begin{array}{l}-0.631 \\
(-1.156)\end{array}$ \\
\hline EEF-Equity Europe & -0.0007 & 0.05008 & $\begin{array}{c}1.005 \\
(132.86)\end{array}$ & 0.997 & $\begin{array}{c}1.005 \\
(113.487)\end{array}$ & $\begin{array}{l}0.012 \\
(0.12)\end{array}$ \\
\hline MSCI EUROPE INDEX & -0.0015 & 0.04977 & 1 & 1 & & \\
\hline
\end{tabular}

$\mu$ - average monthly log return; $\sigma_{d}$ - total risk (standard deviation on fund); $\beta$-systematic risk; $\mathrm{R}^{2}$ - statistics is obtained from the equation $1 ;$ coefficients $\left(\beta^{*}, \gamma\right)$ are estimated with the regression equation 2 ; the benchmark used is the MSCI Europe Index; the average year return of riskfree assets in the observed period is 3.69\%; t-statistics is significant at a $5 \%$ level.

Table 2: Monthly Log Returns of Mutual Funds with Investment Policies in Europe

\begin{tabular}{|l|c|c|c|c|c|}
\hline Mutual Fund & $\mathbf{M}^{2}$ & Th & $\mathbf{a}$ & $\mathbf{S}$ & IR \\
\hline VB-Europa Invest & 0.0159 & -0.02346 & $\begin{array}{c}0.003 \\
(0.762)\end{array}$ & -0.14972 & 0.17026 \\
\hline PIA-Select Europe Stock & 0.0066 & -0.03142 & $\begin{array}{c}0.002 \\
(0.998)\end{array}$ & -0.22107 & 0.47437 \\
\hline Raiffeisen Europa Aktien & -0.0015 & -0.03971 & $\begin{array}{c}0.002 \\
(0.678)\end{array}$ & -0.27196 & 0.10168 \\
\hline EEF-Equity Europe & -0.0082 & -0.04514 & $\begin{array}{c}0.0001 \\
(2.01)\end{array}$ & -0.32131 & 0.92198 \\
\hline Infond Europa & -0.0085 & -0.04885 & $\begin{array}{c}0.001 \\
(0.168)\end{array}$ & -0.30620 & -0.01431 \\
\hline SGAM-Equities Europe & -0.0159 & -0.05596 & $\begin{array}{c}-0.001(- \\
0.058)\end{array}$ & -0.35492 & -0.10103 \\
\hline NLB-Evropski delniški & -0.027 & -0.06364 & $\begin{array}{c}0.003 \\
(1.36)\end{array}$ & -0.44725 & 0.68705 \\
\hline PF-Top European Players & -0.0299 & -0.06820 & $\begin{array}{c}-0.001(- \\
0.812)\end{array}$ & -0.47012 & -0.33697 \\
\hline MSCI EUROPE INDEX & -0.0174 & -0.05422 & $\begin{array}{c}0 \\
0\end{array}$ & -0.38103 & 0 \\
\hline
\end{tabular}

Th-Treynor ratio; a-coefficient; S-Sortino ratio; IR-Information ratio.

Table 3: Risk Adjusted Statistics of Mutual Funds with Investment Policies in Europe 


\begin{tabular}{|c|c|c|c|c|c|c|}
\hline Mutual Funds & $\boldsymbol{\mu}$ & $\sigma D$ & $\boldsymbol{\beta}$ & $\mathbf{R}^{\mathbf{2}}$ & $\beta^{*}$ & $\mathbf{Y}$ \\
\hline Infond Energy & -0.0004 & 0.07250 & $\begin{array}{c}1.018 \\
(11.648)\end{array}$ & 0.755 & $\begin{array}{l}1.001 \\
(9.84)\end{array}$ & $\begin{array}{l}-0.365 \\
(-0.32)\end{array}$ \\
\hline KD-Surovina in energija & -0.0035 & 0.06990 & $0.936(9.807)$ & 0.722 & $\begin{array}{c}0.897 \\
(7.773)\end{array}$ & $\begin{array}{c}-0.78 \\
(-0.63)\end{array}$ \\
\hline EEF-Energy\&Materials & 0.0031 & 0.06132 & $\begin{array}{c}0.928 \\
(23.964)\end{array}$ & 0.914 & $\begin{array}{c}0.909 \\
(21.752)\end{array}$ & $\begin{array}{l}-0.587 \\
(-1.18)\end{array}$ \\
\hline Ilirika-Modra energija & -0.0092 & 0.07156 & $0.871(8.016)$ & 0.675 & $\begin{array}{c}0.841 \\
(6.337) \\
\end{array}$ & $\begin{array}{l}-0.585 \\
(-0.41) \\
\end{array}$ \\
\hline MP-Energy & -0.0038 & 0.07202 & $0.937(9.016)$ & 0.649 & $\begin{array}{c}0.892 \\
(7.403)\end{array}$ & $\begin{array}{l}-1.026 \\
(-0.77) \\
\end{array}$ \\
\hline NLB-Naravni viri & -0.0015 & 0.06177 & $\begin{array}{c}0.867 \\
(11.205)\end{array}$ & 0.754 & $\begin{array}{c}0.86 \\
(9.188)\end{array}$ & $\begin{array}{l}-0.143 \\
(-0.14)\end{array}$ \\
\hline PIA-Energy Stock & 0.0057 & 0.07374 & $\begin{array}{c}1.032 \\
(13.891) \\
\end{array}$ & 0.781 & $\begin{array}{c}0.976 \\
(12.399) \\
\end{array}$ & $\begin{array}{l}-1.743 \\
(-1.86) \\
\end{array}$ \\
\hline Raiffeisen Energie Aktien & 0.0041 & 0.07221 & $\begin{array}{c}1.044 \\
(16.442)\end{array}$ & 0.834 & $\begin{array}{c}1.003 \\
(14.781)\end{array}$ & $\begin{array}{l}-1.254 \\
(-1.55) \\
\end{array}$ \\
\hline SGAM- Global Energy & -0.0033 & 0.06711 & $0.928(13.23)$ & 0.764 & $\begin{array}{c}0.842 \\
(11.989) \\
\end{array}$ & $\begin{array}{l}-2.669 \\
(-3.19) \\
\end{array}$ \\
\hline MSCI WORLD ENERGY INDEX & 0.003 & 0.06319 & 1 & 1 & & \\
\hline
\end{tabular}

$\mu$ - average monthly log return; $\sigma D$ - total risk (standard deviation on fund); $\beta$-systematic risk; $R^{2}$ - statistics obtained from the equation 1 ; coefficients $\left(\beta^{*}, \gamma\right)$ are estimated with the regression equation 2; benchmark used is MSCI Energy Index; average year return of a risk-free asset in the observed period is 3.09\%; t-statistics is significant at a $5 \%$ level.

Table 4: Monthly Log Returns of Mutual funds with Investment Policies in the Energy Sector

\begin{tabular}{|l|c|c|c|c|c|}
\hline Mutual Funds & $\mathbf{M}^{2}$ & Th & $\mathbf{a}$ & $\mathbf{S}$ & $\mathbf{I R}$ \\
\hline PIA-Energy Stock & 0.0633 & 0.03656 & $\begin{array}{c}0.003 \\
(0.57)\end{array}$ & 0.18033 & 0.26953 \\
\hline Raiffeisen Energie Aktien & 0.0471 & 0.01771 & $\begin{array}{c}0.001 \\
(0.266)\end{array}$ & 0.09083 & 0.12693 \\
\hline EEF-Energy\&Materials & 0.0375 & 0.00688 & $\begin{array}{c}0.0001 \\
(0.043)\end{array}$ & 0.03559 & 0.01409 \\
\hline Infond Energy & 0.0002 & -0.03467 & $\begin{array}{c}0.003 \\
(0.596)\end{array}$ & -0.17307 & 0.30222 \\
\hline NLB-Naravni viri & -0.0191 & -0.05633 & $\begin{array}{c}0.004 \\
(0.85)\end{array}$ & -0.28746 & 0.58735 \\
\hline KD-Surovina in energija & -0.0348 & -0.07754 & $\begin{array}{c}0.002 \\
(0.262)\end{array}$ & -0.35489 & 0.19814 \\
\hline SGAM-Global Energy & -0.035 & -0.07536 & $\begin{array}{c}-0.006 \\
(-1.412)\end{array}$ & -0.36084 & -0.66251 \\
\hline MP-Energy & -0.0359 & -0.08123 & $\begin{array}{c}-0.001 \\
(-0.102)\end{array}$ & -0.37207 & -0.02223 \\
\hline Ilirika-Modra energija & -0.0936 & -0.16191 & $\begin{array}{c}-0.003 \\
(-0.39)\end{array}$ & -0.64531 & -0.13109 \\
\hline MSCI WORLD ENERGY INDEX & 0.0364 & -0.00548 & $\begin{array}{c}0 \\
0\end{array}$ & 0.02998 & 0 \\
\hline
\end{tabular}

Th-Treynor ratio; a-coefficient; S-Sortino ratio; IR-Information ratio.

Table 5: Risk Adjusted Statistics of Mutual Funds with Investment Policies in the Energy Sector 